\title{
Adsorption Mechanism of Heavy Metals in Heavy Metal/Pesticide Coexisting Sediment Systems through Factional Factorial Design Assisted by 2D-QSAR Models
}

\author{
Zhenhua Chu, Wenwen Gu, Yu Li* \\ College of Environmental Science and Engineering, North China Electric Power University, \\ Beijing, China
}

Received: 2 October 2017

Accepted: 3 December 2017

\begin{abstract}
Resolution $\mathrm{V}$ of the $2^{10-3}$ fractional factorial design method was used to identify the main effects and second-order interaction effects of pollutants (copper, cadmium, lead, zinc, nickel, dimethoate, metalaxyl, atrazine, malathion, and prometryn) on metals adsorption onto sediments, and 2D-QSAR models were established to reveal the relationships between metal ion characteristics and the effects of pollutants on metals adsorption. The effects on $\mathrm{Cd}$ adsorption were attributed to the main effects of pollutant factor concentrations, while the effects on $\mathrm{Cu}, \mathrm{Pb}, \mathrm{Zn}$, and $\mathrm{Ni}$ adsorption were from the second-order interaction effect. No interference with Cd adsorption was observed, and the synergistic contribution of the main effects and second-order interaction effects on $\mathrm{Ni}$ adsorption was $67.26 \%$. Additionally, the antagonistic contribution rates to $\mathrm{Cu}, \mathrm{Zn}$, and $\mathrm{Pb}$ adsorption reached $55.31 \%, 73.16 \%$, and $86.23 \%$, respectively. Significant correlations existed between the main effects and ionization potential (IP), the change in ionization potential $(\triangle \mathrm{IP})$ and ion hydrolysis ability of metals, and the second-order interaction effects with atomic number, atomic weight, and polarizing power $\left(Z^{2} / r\right)$ of metals. The electrochemical potential, $\triangle \mathrm{IP}$ and IP of metals were found to promote adsorption, $Z^{2} / \mathrm{r}$, electronegativity and atomic radius of metals to inhibit adsorption significantly. Overall, the results provide theoretical support that helps elucidate compound pollution regulation among heavy metal pollutants in complex environmental systems.
\end{abstract}

Keywords: adsorption mechanism, fractional factorial design, heavy metals, pesticides, 2D-QSAR model

*e-mail: liyuxx8@hotmail.com 


\section{Introduction}

The rapid development of industry and agriculture has led to the production of large amounts of heavy metals and pesticides, which have often entered and gradually accumulated in the environment [1-2]. This has caused serious pollution of water [3], the atmosphere [4], and soil [5], and has threatened the health of animals, plants, and humans [6-7]. In addition to their own environmental pollution, the interactions among heavy metals and pesticides may also produce synergistic or antagonistic effects to form compound pollution [8-9]. The combined pollution effects lead to changes in the migration and transformation pathways as well as in the biological effects of pollutants within different environmental media [10].

Sediment consists of tiny particles that move with fluid flow and eventually become a layer comprising a solid particle system at the bottom of an aquatic system. Because of its unique structure, sediment can become enriched with heavy metals and pesticides because it has significant adsorption effects on pollutants in the environment [11-12]. Sediment is the source and sink of many pollutants in aquatic environments [13-14], and an important carrier facilitating the migration of pollutants in natural aquatic systems [15]. Therefore, several researchers have conducted studies evaluating the adsorption behavior of heavy metals and pesticides in sediments, including investigations of heavy metals and pesticide content in different geographical sediments [1618 ] and analyses of pollutant adsorption characteristics of sediments exposed to compound pollution [19-21].

To investigate compound pollution, researchers usually use orthogonal design, factorial design, central composite design, and other experimental design methods; however, when the interactions of multiple experimental factors are taken into consideration, the fractional factor design can effectively reduce the scale of the experiment [22]. Wang et al. used resolution III of the $2^{10-6}$ fractional factorial design method assisted by a complete foldover design and confounding design to explore the adsorption characteristics of dimethoate and a variety of pollutants on sediments [23]. In their study, they solved the alias structure between the main effect and the second-order interaction effect, but could not clearly identify the second-order interaction effect. $\mathrm{Gu}$ et al. [24] and Cheng [25] further differentiated the influence of each second-order interaction effect on target pollutants and used resolution $\mathrm{V}$ of the $2^{10-3}$ fractional factorial design method to investigate the cadmium and nickel competitive adsorption characteristics under a heavy metal (copper, cadmium, lead, zinc, and nickel) and pesticide (dimethoate, metalaxyl, atrazine, malathion, and prometryn) coexisting sediment system while focusing on the adsorption characteristics of a single heavy metal in the compound pollution system. However, they were not able to explain the heavy metals adsorption mechanism based on their nature when they coexisted. Therefore, the present study employed a fixed effect model of resolution $\mathrm{V}$ of the $2^{10-3}$ fractional factorial design method to investigate the adsorption characteristics of copper, lead, and zinc in the system mentioned above. Construction of the 2D-QSAR model helped elucidate the adsorption mechanism of heavy metals in the composite pollution system. Overall, the results of this study provide a theoretical basis for the regulation of heavy metal pollutants in aquatic environments.

\section{Material and Methods}

\section{Collection and Preparation of Samples}

Sediment samples were collected from the Songhua River located in Jilin City, Jilin Province, China. Samples were taken from the sediment surface layer $(0-5 \mathrm{~cm}$ in depth) with a bucket-type sampler, and 4 samples from the same sampling point were mixed uniformly into a single sample. All samples were then filtered to remove water, separated from stones and debris, packed in plastic bags, and transported to the laboratory. Finally, samples were naturally air dried, ground, sieved, and transferred into a sealed jar [26].

\section{Experimental Methods and Designs}

Five heavy metals - copper (A), cadmium (B), lead (C), zinc (D) and nickel (E) - and 5 pesticides dimethoate $(F)$, metalaxyl $(\mathrm{G})$, atrazine $(\mathrm{H})$, malathion $(\mathrm{J})$ and prometryn $(\mathrm{K})$ - were selected as the experimental factors. The 5 heavy metals were the target pollutants used to explore the heavy metals characteristics of migration and transformation in the water environment through the competitive adsorption of various pollutants. The concentrations of heavy metals and pesticides were 60-150 $\mu \mathrm{mol} / \mathrm{L}$ and $10-25 \mu \mathrm{mol} / \mathrm{L}$, respectively. Resolution $\mathrm{V}$ of the $2^{10-3}$ fractional factorial design method was used to set the concentration of 10 contaminants in each mixed solution, and the parallel samples and blank samples were set with a total of 384 groups. For 256 groups, $20 \mathrm{~mL}$ of mixed solution was transferred into a conical flask containing $0.5000 \pm 0.0001 \mathrm{~g}$ of sediment samples, while for the other 128 groups, $20 \mathrm{~mL}$ of mixed solution was set into a conical flask without sediments, then shaken for $48 \mathrm{~h}$ and filtered through a $0.22 \mu \mathrm{m}$ membrane. The concentration of pesticides and heavy metals in the solution was determined by high-performance liquid chromatography (HPLC) and flame atomic absorption spectrophotometry, and the difference between the concentration of contaminants in the blank solution and the solution after adsorption was used to calculate the heavy metals adsorption in sediments [26]. The experimental data describing the heavy metal absorption onto the sediments is shown in Table 1.

The principle of resolution $\mathrm{V}$ of the $2^{10-3}$ fractional factorial design method determined the generators of the main and interaction effects of the pollutant factor concentration. The alias structures were as follows. 
Table 1. Heavy metal absorption on sediments in heavy metal and pesticide system ( $\mu \mathrm{mol} / \mathrm{g})$.

\begin{tabular}{|c|c|c|c|c|c|c|c|c|c|c|c|}
\hline \multirow{2}{*}{ No. } & \multicolumn{5}{|c|}{ Adsorption } & \multirow{2}{*}{ No. } & \multicolumn{5}{|c|}{ Adsorption } \\
\hline & $\mathrm{Cu}$ & $\mathrm{Cd}$ & $\mathrm{Pb}$ & $\mathrm{Zn}$ & $\mathrm{Ni}$ & & $\mathrm{Cu}$ & $\mathrm{Cd}$ & $\mathrm{Pb}$ & $\mathrm{Zn}$ & $\mathrm{Ni}$ \\
\hline 1 & 10.75 & 16.68 & 7.66 & 10.22 & 5.49 & 65 & 6.95 & 6.39 & 1.90 & 9.31 & 8.60 \\
\hline 2 & 11.29 & 7.63 & 7.98 & 7.58 & 13.14 & 66 & 9.75 & 1.69 & 4.07 & 12.02 & 20.28 \\
\hline 3 & 11.07 & 11.43 & 20.59 & 7.33 & 3.25 & 67 & 21.59 & 3.51 & 17.25 & 4.33 & 7.43 \\
\hline 4 & 21.93 & 11.65 & 6.45 & 4.34 & 4.02 & 68 & 23.23 & 7.47 & 6.18 & 8.59 & 23.31 \\
\hline 5 & 2.79 & 1.40 & 0.03 & 0.21 & 0.59 & 69 & 24.61 & 10.07 & 21.31 & 4.95 & 1.21 \\
\hline 6 & 12.75 & 13.95 & 21.51 & 8.08 & 13.22 & 70 & 23.38 & 4.70 & 6.78 & 5.78 & 2.80 \\
\hline 7 & 22.47 & 5.83 & 21.36 & 4.93 & 5.54 & 71 & 22.95 & 13.84 & 6.90 & 8.27 & 3.65 \\
\hline 8 & 28.80 & 4.50 & 9.22 & 11.86 & 11.26 & 72 & 27.73 & 20.91 & 8.03 & 8.11 & 19.32 \\
\hline 9 & 12.04 & 7.71 & 20.35 & 8.06 & 16.18 & 73 & 24.07 & 10.01 & 19.46 & 3.91 & 5.74 \\
\hline 10 & 21.89 & 11.10 & 7.76 & 4.31 & 8.71 & 74 & 9.48 & 6.72 & 15.02 & 10.69 & 5.38 \\
\hline 11 & 22.88 & 6.39 & 7.01 & 5.16 & 13.14 & 75 & 24.91 & 3.18 & 19.05 & 6.60 & 1.08 \\
\hline 12 & 20.74 & 9.71 & 6.58 & 5.18 & 3.06 & 76 & 10.52 & 11.50 & 17.81 & 7.07 & 7.51 \\
\hline 13 & 11.51 & 6.57 & 20.14 & 5.90 & 5.24 & 77 & 9.06 & 8.24 & 5.53 & 13.93 & 7.97 \\
\hline 14 & 9.60 & 11.08 & 5.80 & 8.13 & 3.44 & 78 & 11.54 & 6.70 & 18.68 & 9.51 & 5.40 \\
\hline 15 & 10.65 & 13.72 & 18.72 & 6.30 & 4.79 & 79 & 10.73 & 2.30 & 5.65 & 12.08 & 16.90 \\
\hline 16 & 13.20 & 6.70 & 23.81 & 7.02 & 14.40 & 80 & 9.77 & 18.50 & 5.70 & 6.91 & 4.93 \\
\hline 17 & 10.58 & 10.54 & 18.54 & 5.87 & 3.71 & 81 & 11.16 & 14.29 & 17.88 & 10.45 & 16.89 \\
\hline 18 & 22.33 & 11.58 & 7.43 & 6.18 & 9.76 & 82 & 11.09 & 12.97 & 20.19 & 7.77 & 3.17 \\
\hline 19 & 18.50 & 13.83 & 6.18 & 3.71 & 6.89 & 83 & 24.19 & 14.98 & 6.40 & 6.72 & 4.00 \\
\hline 20 & 9.67 & 5.72 & 5.86 & 9.61 & 10.19 & 84 & 18.27 & 2.22 & 14.26 & 0.90 & 2.32 \\
\hline 21 & 15.05 & 8.89 & 3.98 & 3.58 & 8.81 & 85 & 12.23 & 8.90 & 19.59 & 3.75 & 5.70 \\
\hline 22 & 10.23 & 6.61 & 18.65 & 10.09 & 5.64 & 86 & 22.81 & 6.65 & 27.07 & 7.33 & 11.12 \\
\hline 23 & 13.54 & 7.66 & 24.44 & 10.14 & 16.77 & 87 & 23.80 & 9.06 & 8.14 & 6.29 & 2.53 \\
\hline 24 & 11.22 & 8.85 & 6.77 & 10.93 & 6.25 & 88 & 10.21 & 21.95 & 5.56 & 24.99 & 8.89 \\
\hline 25 & 11.58 & 17.33 & 7.99 & 7.74 & 14.11 & 89 & 10.11 & 15.95 & 5.74 & 7.20 & 10.94 \\
\hline 26 & 22.63 & 4.67 & 21.49 & 5.02 & 10.87 & 90 & 8.17 & 6.96 & 3.52 & 7.88 & 5.35 \\
\hline 27 & 10.14 & 6.64 & 6.47 & 12.09 & 5.55 & 91 & 12.47 & 23.56 & 6.75 & 10.74 & 7.20 \\
\hline 28 & 23.03 & 5.67 & 6.98 & 7.81 & 4.35 & 92 & 22.98 & 4.91 & 6.29 & 5.84 & 1.00 \\
\hline 29 & 12.61 & 11.33 & 7.69 & 13.85 & 7.08 & 93 & 10.80 & 16.14 & 5.82 & 10.77 & 5.64 \\
\hline 30 & 23.46 & 11.12 & 8.37 & 5.74 & 3.25 & 94 & 9.68 & 10.01 & 6.01 & 5.21 & 4.69 \\
\hline 31 & 12.94 & 17.10 & 20.06 & 8.75 & 4.16 & 95 & 19.39 & 10.59 & 5.03 & 6.19 & 5.12 \\
\hline 32 & 13.36 & 8.68 & 22.80 & 8.44 & 6.77 & 96 & 9.86 & 9.04 & 11.00 & 1.92 & 4.91 \\
\hline 33 & 24.07 & 5.63 & 7.40 & 7.81 & 4.13 & 97 & 28.48 & 20.64 & 22.17 & 10.33 & 1.97 \\
\hline 34 & 9.64 & 7.44 & 5.43 & 11.83 & 4.42 & 98 & 23.90 & 4.09 & 16.31 & 4.23 & 4.59 \\
\hline 35 & 10.31 & 15.08 & 7.42 & 8.09 & 4.19 & 99 & 8.78 & 7.81 & 4.99 & 15.91 & 2.04 \\
\hline 36 & 17.89 & 1.05 & 18.68 & 2.81 & 4.43 & 100 & 25.24 & 11.88 & 20.34 & 7.18 & 5.24 \\
\hline 37 & 10.89 & 7.58 & 18.26 & 7.57 & 6.65 & 101 & 11.44 & 6.03 & 17.56 & 9.02 & 10.39 \\
\hline 38 & 18.73 & 4.80 & 19.54 & 2.81 & 6.33 & 102 & 24.81 & 4.67 & 19.32 & 6.15 & 2.37 \\
\hline 39 & 11.65 & 6.78 & 20.77 & 7.79 & 4.59 & 103 & 11.43 & 15.99 & 19.02 & 7.51 & 10.67 \\
\hline
\end{tabular}


Table 1. Continued.

\begin{tabular}{|c|c|c|c|c|c|c|c|c|c|c|c|}
\hline \multirow{2}{*}{ No. } & \multicolumn{5}{|c|}{ Adsorption } & \multirow{2}{*}{ No. } & \multicolumn{5}{|c|}{ Adsorption } \\
\hline & $\mathrm{Cu}$ & $\mathrm{Cd}$ & $\mathrm{Pb}$ & $\mathrm{Zn}$ & $\mathrm{Ni}$ & & $\mathrm{Cu}$ & $\mathrm{Cd}$ & $\mathrm{Pb}$ & $\mathrm{Zn}$ & $\mathrm{Ni}$ \\
\hline 40 & 20.75 & 8.10 & 6.65 & 4.39 & 7.51 & 104 & 19.83 & 2.39 & 16.61 & 3.05 & 2.68 \\
\hline 41 & 23.08 & 5.35 & 7.73 & 3.55 & 22.53 & 105 & 25.98 & 6.26 & 23.86 & 2.26 & 1.81 \\
\hline 42 & 7.85 & 15.38 & 32.17 & 2.15 & 16.60 & 106 & 23.81 & 12.38 & 19.47 & 7.08 & 2.81 \\
\hline 43 & 18.01 & 8.97 & 18.45 & 3.35 & 9.11 & 107 & 13.32 & 12.56 & 3.95 & 14.22 & 21.73 \\
\hline 44 & 23.22 & 4.59 & 7.89 & 6.90 & 7.39 & 108 & 12.58 & 9.62 & 7.66 & 11.75 & 10.11 \\
\hline 45 & 18.87 & 5.57 & 17.98 & 2.11 & 6.77 & 109 & 23.75 & 12.65 & 19.60 & 4.81 & 0.10 \\
\hline 46 & 12.67 & 16.07 & 19.93 & 7.00 & 18.01 & 110 & 19.88 & 14.43 & 4.51 & 5.94 & 2.67 \\
\hline 47 & 22.79 & 2.93 & 21.19 & 3.78 & 0.94 & 111 & 9.05 & 15.29 & 4.43 & 10.48 & 2.42 \\
\hline 48 & 8.85 & 6.80 & 4.75 & 8.17 & 3.73 & 112 & 25.47 & 6.94 & 18.64 & 7.24 & 3.31 \\
\hline 49 & 10.98 & 8.34 & 6.70 & 11.83 & 2.72 & 113 & 10.97 & 15.40 & 17.36 & 7.47 & 0.55 \\
\hline 50 & 11.04 & 5.99 & 8.42 & 9.12 & 7.86 & 114 & 25.86 & 7.64 & 7.99 & 1.44 & 9.34 \\
\hline 51 & 21.35 & 3.94 & 19.05 & 4.97 & 4.70 & 115 & 11.88 & 6.65 & 17.19 & 6.37 & 2.39 \\
\hline 52 & 23.48 & 3.61 & 21.69 & 5.33 & 5.82 & 116 & 10.23 & 7.15 & 17.53 & 3.29 & 1.41 \\
\hline 53 & 25.55 & 7.71 & 7.58 & 8.41 & 9.71 & 117 & 19.93 & 4.37 & 5.83 & 1.43 & 0.88 \\
\hline 54 & 10.08 & 7.47 & 6.47 & 7.81 & 3.44 & 118 & 22.23 & 5.49 & 6.32 & 5.66 & 5.04 \\
\hline 55 & 21.55 & 4.79 & 18.44 & 2.41 & 2.45 & 119 & 9.73 & 9.35 & 17.42 & 9.58 & 2.09 \\
\hline 56 & 12.96 & 27.48 & 22.58 & 5.38 & 12.80 & 120 & 20.35 & 3.85 & 19.10 & 1.44 & 8.19 \\
\hline 57 & 9.81 & 5.71 & 6.17 & 6.73 & 3.67 & 121 & 33.75 & 10.78 & 30.60 & 8.71 & 8.03 \\
\hline 58 & 12.29 & 8.38 & 20.16 & 6.34 & 4.42 & 122 & 9.30 & 5.73 & 4.86 & 6.11 & 4.19 \\
\hline 59 & 11.64 & 0.89 & 20.53 & 1.99 & 1.67 & 123 & 21.23 & 8.08 & 5.28 & 8.74 & 5.81 \\
\hline 60 & 1.56 & 4.75 & 0.53 & 3.13 & 6.93 & 124 & 8.30 & 12.68 & 4.47 & 8.65 & 4.70 \\
\hline 61 & 23.68 & 9.71 & 21.05 & 4.73 & 3.54 & 125 & 9.71 & 16.01 & 6.15 & 9.18 & 6.78 \\
\hline 62 & 20.45 & 3.52 & 21.20 & 1.58 & 7.08 & 126 & 21.02 & 10.48 & 5.36 & 4.18 & 0.80 \\
\hline 63 & 18.98 & 7.14 & 21.53 & 1.96 & 5.91 & 127 & 22.30 & 7.66 & 5.85 & 7.78 & 3.26 \\
\hline 64 & 0.52 & 11.56 & 6.06 & 6.73 & 2.64 & 128 & 23.58 & 5.55 & 6.31 & 4.66 & 6.74 \\
\hline
\end{tabular}

Aliases of the main effects of the pollutant factor concentration: $\mathrm{A}=\mathrm{EFHJ}, \mathrm{B}=\mathrm{CFGH}, \mathrm{C}=\mathrm{BFGH}$, $\mathrm{D}=\mathrm{GHJK}, \mathrm{E}=\mathrm{AFHJ}, \mathrm{F}=\mathrm{BCGH}=\mathrm{AEHJ}, \mathrm{G}=\mathrm{BCFH}$ $=$ DHJK, $\mathrm{H}=\mathrm{BCFG}=\mathrm{AEFJ}=\mathrm{DGJK}, \mathrm{J}=\mathrm{AEFH}=$ DGHK, $\mathrm{K}=$ DGHJ.

Aliases of the second-order interaction effects of the pollutant factor concentration: $\mathrm{AB}=\mathrm{CEGJ}, \mathrm{AC}=\mathrm{BEGJ}$, $\mathrm{AD}=\mathrm{EFGK}, \mathrm{AE}=\mathrm{FHJ}=\mathrm{DFGK}=\mathrm{BCGJ}, \mathrm{AF}=\mathrm{EHJ}$ $=\mathrm{DEGK}, \mathrm{AG}=\mathrm{DEFK}=\mathrm{BCEJ}, \mathrm{AH}=\mathrm{EFJ}, \mathrm{AJ}=\mathrm{EFH}$ $=\mathrm{BCEG}, \mathrm{AK}=\mathrm{DEFG}, \mathrm{BC}=\mathrm{FGH}=\mathrm{DFJK}=\mathrm{AEGJ}$, $\mathrm{BD}=\mathrm{CFJK}, \mathrm{BE}=\mathrm{ACGJ}, \mathrm{BF}=\mathrm{CGH}=\mathrm{CDJK}, \mathrm{BG}=\mathrm{CFH}$ $=\mathrm{ACEJ}, \mathrm{BH}=\mathrm{CFG}, \mathrm{BJ}=\mathrm{CDFK}=\mathrm{ACEG}, \mathrm{BK}=\mathrm{CDFJ}$, $\mathrm{CD}=\mathrm{BFJK}, \mathrm{CE}=\mathrm{ABGJ}, \mathrm{CF}=\mathrm{BGH}=\mathrm{BDJK}, \mathrm{CG}=\mathrm{BFH}$ $=\mathrm{ABEJ}, \mathrm{CH}=\mathrm{BFG}, \mathrm{CJ}=\mathrm{BDFK}=\mathrm{ABEG}, \mathrm{CK}=\mathrm{BDFJ}$,
$\mathrm{DE}=\mathrm{AFGK}, \mathrm{DF}=\mathrm{AEGK}=\mathrm{BCJK}, \mathrm{DG}=\mathrm{HJK}=\mathrm{AEFK}$, $\mathrm{DH}=\mathrm{GJK}, \mathrm{DJ}=\mathrm{GHK}=\mathrm{BCFK}, \mathrm{DK}=\mathrm{GHJ}=\mathrm{AEFG}$ $=\mathrm{BCFJ}, \mathrm{EF}=\mathrm{AHJ}=\mathrm{ADGK}, \mathrm{EG}=\mathrm{ADFK}=\mathrm{ABCJ}$, $\mathrm{EH}=\mathrm{AFJ}, \mathrm{EJ}=\mathrm{AFH}=\mathrm{ABCG}, \mathrm{EK}=\mathrm{ADFG}, \mathrm{FG}=$ $\mathrm{BCH}=\mathrm{ADEK}, \mathrm{FH}=\mathrm{BCG}=\mathrm{AEJ}, \mathrm{FJ}=\mathrm{AEH}=\mathrm{BCDK}$, $\mathrm{FK}=\mathrm{ADEG}=\mathrm{BCDJ}, \mathrm{GH}=\mathrm{BCF}=\mathrm{DJK}, \mathrm{GJ}=\mathrm{DHK}$ $=\mathrm{ABCE}, \mathrm{GK}=\mathrm{DHJ}=\mathrm{ADEF}, \mathrm{HJ}=\mathrm{AEF}=\mathrm{DGK}, \mathrm{HK}$ $=\mathrm{DGJ}, \mathrm{JK}=\mathrm{DGH}=\mathrm{BCDF}$.

The above alias structure demonstrates that, when the third-order and above interaction effects are neglected, resolution $\mathrm{V}$ of the $2^{10-3}$ fractional factorial design method can completely distinguish the main effects and the second-order interaction effects of the pollutant factor concentration. 


\section{Results and Discussion}

The design of experiment (DOE) function in the Minitab software was used to establish the fixed effect model of resolution $\mathrm{V}$ of the $2^{10-3}$ fractional factorial design. The variance in the relationship between the pollutant factor concentration and the adsorption capacity of heavy metals on sediments, as well as the effect value estimation of the main effects and the second-order interaction effects of the pollutant factor concentration on the heavy metal adsorption by sediments were analyzed. According to the $\mathrm{P}$ value (significance level $\mathrm{P}=0.05$ ) of the effect value estimation, the main effects and second-order interaction effects of each pollutant factor concentration were analyzed to determine if the pollutant factor had a significant effect on heavy metals adsorption.

\section{Adsorption Characteristic Analysis of Heavy Metals} Based on the Fixed Effect Model

\section{Variance Analysis}

In resolution $\mathrm{V}$ of the $2^{10-3}$ fractional factorial design, variance analysis of the main effects and the second-order interaction effects of the pollutant factor concentration on the adsorption capacity of the heavy metals was conducted using the fixed effects model (Table 2).

The variance analysis was used to test whether the main effects and the second-order interaction effects of the pollutant factor concentration generally had a significant effect on the heavy metals adsorption. The degrees of freedom reflect the number of main effects and second-order interaction effects of pollutant factor concentration that can be evaluated. The $\mathrm{P}$ value represents the diminishing index of the result reliability - namely the significance level, which is usually 0.05 . As shown in Table 2, the main effects and second-order interaction effects of pollutant factor concentration $(\mathrm{P}<0.05)$ have a significant effect on the adsorption of $\mathrm{Cu}, \mathrm{Pb}$, and $\mathrm{Ni}$, while the second-order interaction effects $(\mathrm{P}<0.05)$ have a significant effect on the adsorption of $\mathrm{Zn}$ by sediments, and the main effects $(\mathrm{P}<0.05)$ have a significant effect on $\mathrm{Cd}$ adsorption. Therefore, it is necessary to screen out the specific main effects and second-order interaction effects of pollutant factor concentrations in order to analyze the mechanism of heavy metals adsorption onto sediments.

Table 2. Variance analysis of the effects of pollutant factor concentrations on heavy metal adsorption.

\begin{tabular}{|c|c|c|c|c|c|c|}
\hline Heavy metal & Source & $\mathrm{DF}$ & SS & MS & $\mathrm{F}$ & $\mathrm{P}$ \\
\hline \multirow{4}{*}{$\mathrm{Cu}$} & Main effect & 10 & 1074 & 107.3666 & 21.85 & 0.030 \\
\hline & Second-order interaction & 45 & 364 & 8.09 & 1.21 & 0.016 \\
\hline & Residual error & 72 & 190 & 2.64 & & \\
\hline & Total & 127 & 1628 & & & \\
\hline \multirow{4}{*}{$\mathrm{Pb}$} & Main effect & 10 & 853 & 85.33 & 1.49 & 0.047 \\
\hline & Second-order interaction & 45 & 515 & 11.44 & 1.36 & 0.000 \\
\hline & Residual error & 72 & 437 & 6.07 & & \\
\hline & Total & 127 & 1805 & & & \\
\hline \multirow{4}{*}{$\mathrm{Zn}$} & Main effect & 10 & 133 & 13.32 & 1.20 & 0.065 \\
\hline & Second-order interaction & 45 & 619 & 13.75 & 36.24 & 0.000 \\
\hline & Residual error & 72 & 799 & 11.10 & & \\
\hline & Total & 127 & 1551 & & & \\
\hline \multirow{4}{*}{$\mathrm{Cd}^{\mathrm{a}}$} & Main effect & 10 & 1488 & 148.76 & 45.84 & 0.000 \\
\hline & Second-order interaction & 45 & 211 & 4.70 & 1.45 & 0.080 \\
\hline & Residual error & 72 & 234 & 3.25 & & \\
\hline & Total & 127 & 1933 & & & \\
\hline \multirow{4}{*}{$\mathrm{Ni}^{\mathrm{b}}$} & Main effect & 10 & 710 & 71.00 & 18.64 & 0.000 \\
\hline & Second-order interaction & 45 & 652 & 14.49 & 3.80 & 0.000 \\
\hline & Residual error & 72 & 274 & 3.81 & & \\
\hline & Total & 127 & 1636 & & & \\
\hline
\end{tabular}

${ }^{a}$ Gu et al. (2017), ${ }^{b}$ Cheng (2015). DF: degree of freedom; SS: sum of squares; MS: mean square; F: F-test value; P: significance level. The bold terms mean significant at the significance level of 0.05 . 
Table 3. Estimates and contribution rates of the main and second-order interaction effects of significant pollutant factor concentrations on adsorption of heavy metals.

\begin{tabular}{|c|c|c|c|c|c|}
\hline \multirow{2}{*}{ Heavy metal } & \multirow{2}{*}{ Factor } & \multirow{2}{*}{$\begin{array}{l}\text { Estimate } \\
\text { of effect }\end{array}$} & \multirow{2}{*}{$\begin{array}{c}\mathrm{P} \\
(\mathrm{P}<0.05)\end{array}$} & \multicolumn{2}{|c|}{ Contribution rate (\%) } \\
\hline & & & & synergism & antagonism \\
\hline \multirow{6}{*}{$\mathrm{Cu}$} & $\mathrm{Cu}$ & 5.007 & 0.000 & 28.62 & \\
\hline & Metalaxyl ${ }^{*} \mathrm{Cu}$ & -2.759 & 0.044 & & 15.77 \\
\hline & Atrazine*Prometryn & 2.812 & 0.041 & 16.07 & \\
\hline & Malathion*Pb & -2.889 & 0.036 & & 16.51 \\
\hline & $\mathrm{Cu}^{*} \mathrm{~Pb}$ & -4.030 & 0.004 & & 23.03 \\
\hline & Total & 17.497 & & 44.69 & 55.31 \\
\hline \multirow{8}{*}{$\mathrm{Pb}$} & Malathion & -3.264 & 0.017 & & 14.68 \\
\hline & $\mathrm{Pb}$ & 3.061 & 0.025 & 13.77 & \\
\hline & Dimethoate $* \mathrm{Cu}$ & -2.852 & 0.037 & & 12.83 \\
\hline & Metalaxyl*Malathion & -2.793 & 0.041 & & 12.56 \\
\hline & Malathion* $\mathrm{Pb}$ & -4.376 & 0.002 & & 19.68 \\
\hline & Prometryn $* \mathrm{~Pb}$ & -3.012 & 0.028 & & 13.54 \\
\hline & $\mathrm{Pb} * \mathrm{Ni}$ & -2.877 & 0.035 & & 12.94 \\
\hline & Total & 22.235 & & 13.77 & 86.23 \\
\hline \multirow{6}{*}{$\mathrm{Zn}$} & $\mathrm{Cu}$ & -1.402 & 0.020 & & 19.36 \\
\hline & Metalaxyl*Zn & -1.246 & 0.038 & & 17.20 \\
\hline & Atrazine* $\mathrm{Ni}$ & 1.945 & 0.001 & 26.84 & \\
\hline & Prometryn* $\mathrm{Zn}$ & -1.470 & 0.015 & & 20.30 \\
\hline & $\mathrm{Cu}^{*} \mathrm{Ni}$ & -1.181 & 0.049 & & 16.30 \\
\hline & Total & 7.243 & & 26.84 & 73.16 \\
\hline \multirow{8}{*}{$\mathrm{Cd}^{\mathrm{a}}$} & Dimethoate & -0.706 & 0.030 & & 5.03 \\
\hline & $\mathrm{Cu}$ & -2.442 & 0.000 & & 17.41 \\
\hline & $\mathrm{Cd}$ & 5.821 & 0.000 & 41.49 & \\
\hline & $\mathrm{Pb}$ & -1.836 & 0.000 & & 13.09 \\
\hline & $\mathrm{Zn}$ & -1.412 & 0.000 & & 10.06 \\
\hline & $\mathrm{Cu}^{*} \mathrm{Zn}$ & 1.171 & 0.000 & 8.35 & \\
\hline & $\mathrm{Zn} * \mathrm{Ni}$ & -0.641 & 0.048 & & 4.57 \\
\hline & Total & 14.029 & & 49.84 & 50.16 \\
\hline
\end{tabular}

\section{Effect Value Estimation and Contribution Rate Analysis}

In resolution $\mathrm{V}$ of the $2^{10-3}$ fractional factorial design, the fixed effect model can be applied to effect value estimation and contribution rate analysis (Table 3) of the main effects and second-order interaction effects of the pollutant factor concentration, which have significant effects on heavy metals adsorption $(\mathrm{P}<0.05)$.

As shown in Table 3, the factors having significant main effects of the pollutant factor concentration on $\mathrm{Cd}$ adsorption were $\mathrm{Cd}, \mathrm{Cu}, \mathrm{Pb}, \mathrm{Zn}$, and dimethoate, which contributed $87.08 \%$ of the total. Additionally, the significant second-order interaction effects were $\mathrm{Cu}^{*} \mathrm{Zn}$ and $\mathrm{Zn} * \mathrm{Ni}$, which contributed $12.92 \%$ [24]. These findings indicate that the effects on $\mathrm{Cd}$ adsorption can be attributed to the main effects of pollutant factor concentrations. Moreover, in systems in which heavy metals and pesticides coexist, the effects of heavy metals on $\mathrm{Cd}$ adsorption are more obvious. The contribution rates of the main effects and the second-order interaction effects of pollutant factor concentrations on $\mathrm{Ni}$ adsorption were $38.09 \%$ and $61.91 \%$, respectively [25], showing that the effects on $\mathrm{Ni}$ adsorption onto the sediments are due to the second-order interaction effects of pollutant 
Table 3. Continued

\begin{tabular}{|c|c|c|c|c|c|}
\hline \multirow{22}{*}{$\mathrm{Ni}^{\mathrm{b}}$} & Metalaxyl & 1.345 & 0.000 & 5.82 & \\
\hline & $\mathrm{Cu}$ & -0.803 & 0.023 & & 3.47 \\
\hline & $\mathrm{Cd}$ & -0.872 & 0.014 & & 3.77 \\
\hline & $\mathrm{Pb}$ & -0.876 & 0.013 & & 3.79 \\
\hline & $\mathrm{Zn}$ & -0.828 & 0.019 & & 3.58 \\
\hline & $\mathrm{Ni}$ & 4.083 & 0.000 & 17.66 & \\
\hline & Dimethoate*Atrazine & -0.818 & 0.020 & & 3.54 \\
\hline & Dimethoate*Prometryn & 0.989 & 0.005 & 4.28 & \\
\hline & Dimethoate* $\mathrm{Cu}$ & 0.707 & 0.044 & 3.06 & \\
\hline & Dimethoate*Cd & -0.788 & 0.025 & & 3.41 \\
\hline & Dimethoate*Zn & 1.233 & 0.001 & 5.33 & \\
\hline & Metalaxyl*Atrazine & -0.759 & 0.031 & & 3.28 \\
\hline & Metalaxyl*Malathion & -1.087 & 0.002 & & 4.70 \\
\hline & Metalaxyl*Ni & 1.412 & 0.000 & 6.11 & \\
\hline & Atrazine*Prometryn & 1.147 & 0.001 & 4.96 & \\
\hline & Atrazine* $\mathrm{Cd}$ & 1.895 & 0.000 & 8.20 & \\
\hline & Atrazine $* \mathrm{~Pb}$ & 0.755 & 0.032 & 3.26 & \\
\hline & Malathion*Cd & -0.739 & 0.036 & & 3.20 \\
\hline & Malathion*Pb & 0.830 & 0.019 & 3.59 & \\
\hline & Prometryn*Cd & 0.837 & 0.018 & & \\
\hline & $\mathrm{Pb} * \mathrm{Zn}$ & 1.154 & 0.001 & 4.99 & \\
\hline & Total & 23.119 & & 67.26 & 32.74 \\
\hline
\end{tabular}

${ }^{\mathrm{a}} \mathrm{Gu}$ et al. (2017), ${ }^{\mathrm{b}}$ Cheng (2015)

factor concentrations. Moreover, the contribution rates of the main effects of pollutant factor concentrations on the adsorption of $\mathrm{Cu}, \mathrm{Pb}$, and $\mathrm{Zn}$ were lower than those of the second-order interaction effects, demonstrating that the effects on $\mathrm{Cu}, \mathrm{Pb}$, and $\mathrm{Zn}$ adsorption are from the second-order interaction effects of pollutant factor concentrations. The above analysis demonstrates that the second-order interaction effects of pollutant factor concentration play a dominant role in the adsorption of heavy metals $(\mathrm{Cu}, \mathrm{Pb}, \mathrm{Zn}$, and $\mathrm{Ni})$ onto sediments in the same adsorption system; thus, investigating heavy metals/pesticides pollution is of great importance for elucidating the characteristics of heavy metals adsorption onto sediments.

As shown in Table 3, under the same adsorption system there were several differences in the main effects and the second-order interaction effects of the pollutant factor concentrations, which had synergistic or antagonistic effects on the adsorption of five heavy metals on the sediments. The contribution of the main effects and the second-order interaction effects of the pollutant factor concentration with synergistic effects on $\mathrm{Cd}$ absorption was as high as $49.84 \%$, while the contribution rate with antagonistic effects was calculated to be $50.16 \%$, indicating that the synergism and antagonism cancel each other out and reach an equilibrium state [24]. These findings indicate that the coexisting system of heavy metals and pesticides has no interference effect on the adsorption of $\mathrm{Cd}$ onto sediments. The contribution rates of the main effects and the second-order interaction effects with synergism and antagonism on $\mathrm{Ni}$ absorption reached $67.26 \%$ and $32.74 \%$, respectively [25], indicating that the pollutant factor has greater promoting effects on $\mathrm{Ni}$ adsorption in the compound pollution system. The synergism contribution rates of the main effects and the second-order interaction effects to the adsorption of $\mathrm{Cu}$, $\mathrm{Zn}$, and $\mathrm{Pb}$ onto sediments were calculated to be $44.69 \%$, $26.84 \%$, and $13.77 \%$, respectively, while the antagonism contribution rates were $55.31 \%, 73.16 \%$, and $86.23 \%$, respectively. These findings indicate that an antagonistic effect plays a dominant role in $\mathrm{Cu}, \mathrm{Zn}$, and $\mathrm{Pb}$ absorption on sediments, and that in the heavy metal/pesticide coexistence system, the adsorption of $\mathrm{Cu}, \mathrm{Zn}$, and $\mathrm{Pb}$ is enhanced by interference with the pollutant factor.

Finally, the adsorption effect values of the five heavy metals revealed that the competitive adsorption capacity 
of heavy metals on sediments decreased in the order $\mathrm{Ni}>\mathrm{Pb}>\mathrm{Cu}>\mathrm{Cd}>\mathrm{Zn}$.

\section{Adsorption Mechanism Analysis of Heavy Metals based on the 2D-QSAR Model}

Studies have shown that the adsorption capacities of heavy metals are related to their physical and chemical properties [27-28]. To further reveal the mechanism of adsorption of heavy metals onto sediments, this study used multiple linear regressions to establish 2D-QSAR models with 11 selected characteristic ion parameters of heavy metals as independent variables and the main effect values, second-order interaction effect values, synergistic effect values, and antagonistic effect values of heavy metals absorption on sediments as dependent variables. These metal ionic characters represent the structure of atoms in term of mathematical values and could be used to calculate adsorption properties.

\section{Correlation Analysis}

The ion characteristic parameters of the heavy metals selected by the model include: atomic number (AN), Pauling ionic radius (r), Pauling electronegativity $(\mathrm{Xm})$, electrochemical potential $\left(\Delta \mathrm{E}_{0}\right)$, change in ionization potential between the $\mathrm{OX}$ and $\mathrm{OX}^{-1}$ states $(\Delta \mathrm{IP})$, polarizing power $\left(\mathrm{Z}^{2} / \mathrm{r}, \mathrm{Z}\right.$ is the ionic charge), ion hydrolysis ability $\left(\left|\log \mathrm{K}_{\mathrm{OH}}\right|, \mathrm{K}_{\mathrm{OH}}\right.$ from $\mathrm{M}^{\mathrm{n}+}+\mathrm{H}_{2} \mathrm{O} \rightarrow \mathrm{MOH}^{\mathrm{n}-1}+\mathrm{H}^{+}$), soft index ( $\sigma \mathrm{p})$, atomic radius (AR), atomic weight (AW), and ionization potential (IP) [29-30]. The ion characteristic parameters of $\mathrm{Cu}, \mathrm{Cd}, \mathrm{Pb}, \mathrm{Zn}$, and $\mathrm{Ni}$ and their correlations with heavy metal adsorption effect values are shown in Tables 4 and 5, respectively.

As shown in Table 5, when the significance level was 0.05 , the significant correlations between the ion characteristic parameters of heavy metals and the main effect values of heavy metal adsorption were IP, $\triangle I P$, and $\left|\log \mathrm{K}_{\mathrm{OH}}\right|$, and the significant correlations with the secondorder interaction effect values of heavy metal adsorption were $\mathrm{AN}, \mathrm{AW}$, and $\mathrm{Z}^{2} / \mathrm{r}$. Additionally, $\Delta \mathrm{E}_{0}, \Delta \mathrm{IP}$, and IP were significantly correlated with the synergistic effect values of heavy metals adsorption, while $\mathrm{Z}^{2} / \mathrm{r}, \mathrm{Xm}$, and AR were significantly correlated with the antagonistic effect values of heavy metals adsorption.

\section{Construction and Evaluation of the 2D-QSAR Model}

The 2D-QSAR models between the main effect values, second-order interaction effect values, synergistic effect values, and antagonistic effect values of heavy metals adsorption and their significantly relevant ion characteristic parameters of heavy metals are as follows:

$$
\begin{gathered}
Y_{\text {main effect }}=-3.083+0.779 \Delta \mathrm{IP}+0.685 \\
\mathrm{IP}-1.619\left|\log \mathrm{K}_{\mathrm{OH}}\right|
\end{gathered}
$$

Table 4. Partial ion characteristic parameters of heavy metals.

\begin{tabular}{|c|c|c|c|c|c|c|c|c|c|c|c|}
\hline Heavy metal & $\mathrm{AN}$ & $\mathrm{Xm}$ & $\Delta \mathrm{E}_{0}$ & $\mathrm{r}$ & $\left|\log \mathrm{K}_{\mathrm{OH}}\right|$ & $\sigma \mathrm{p}$ & $\mathrm{Z} / \mathrm{r}$ & $\Delta \mathrm{IP}$ & $\mathrm{IP}$ & $\mathrm{AR}$ & $\mathrm{AW}$ \\
\hline $\mathrm{Cu}^{2+}$ & 29 & 1.90 & 0.16 & 0.73 & 8.0 & 0.104 & 5.48 & 12.57 & 20.29 & 1.35 & 63.54 \\
\hline $\mathrm{Cd}^{2+}$ & 48 & 1.69 & 0.40 & 0.95 & 10.1 & 0.081 & 4.21 & 7.91 & 16.91 & 1.48 & 112.40 \\
\hline $\mathrm{Pb}^{2+}$ & 82 & 2.33 & 0.13 & 1.18 & 7.7 & 0.131 & 3.39 & 7.61 & 15.03 & 1.54 & 207.19 \\
\hline $\mathrm{Zn}^{2+}$ & 30 & 1.65 & 0.76 & 0.75 & 9.0 & 0.115 & 5.33 & 8.57 & 17.96 & 1.31 & 65.37 \\
\hline $\mathrm{Ni}^{2+}$ & 28 & 1.91 & 0.23 & 0.69 & 9.9 & 0.126 & 5.80 & 10.52 & 18.17 & 1.25 & 58.71 \\
\hline References & \multicolumn{7}{|c}{ Mccloskey et al., 1996 } & & Wolterbeek and Verburg, 2001 \\
\hline
\end{tabular}

AN: atomic number; AR: atomic radius; AW: atomic weight; r: Pauling ionic radius; Xm: Pauling electronegativity; $\Delta \mathrm{E}_{0}$ : electrochemical potential; IP: ionization potential; $\Delta \mathrm{IP}$ : the change in ionization potential; $\mathrm{Z}^{2} / \mathrm{r}$ : polarizing power; $\left|\log \mathrm{K}_{\mathrm{OH}}\right|$ ion hydrolysis ability; $\sigma p$ : soft index

\begin{tabular}{|c|c|c|c|c|c|c|c|c|c|c|c|}
\hline \multirow{2}{*}{ Effect value } & \multicolumn{11}{|c|}{ Pearson correlation } \\
\hline & $\mathrm{AN}$ & $\mathrm{AR}$ & AW & $\mathrm{r}$ & $\mathrm{Xm}$ & $\Delta \mathrm{E}_{0}$ & IP & $\Delta \mathrm{IP}$ & $\mathrm{Z}^{2} / \mathrm{r}$ & $\left|\log \mathrm{K}_{\mathrm{OH}}\right|$ & $\sigma \mathrm{p}$ \\
\hline Main effect & -0.336 & -0.211 & -0.323 & -0.362 & 0.088 & -0.415 & $0.852 *$ & $0.864 *$ & 0.378 & $-0.944 *$ & -0.077 \\
\hline Second-order interaction & $0.901 *$ & -0.813 & $0.869 *$ & -0.852 & -0.679 & 0.235 & 0.604 & 0.455 & $0.879 *$ & 0.779 & -0.249 \\
\hline Synergistic effect & -0.164 & 0.052 & -0.158 & -1.156 & 0.122 & $-0.949 *$ & $0.877^{*}$ & $-0.863 *$ & 0.150 & -0.297 & -0.357 \\
\hline Antagonistic effect & -0.828 & $-0.984 *$ & -0.726 & -0.600 & $-0.960 *$ & 0.439 & 0.737 & 0.571 & $-0.947 *$ & 0.343 & 0.105 \\
\hline
\end{tabular}

Table 5. Correlation analysis of the ion characteristic parameters of heavy metals and the effect values of heavy metal adsorption.

* Statistically significant correlation at level of 0.05 
Table 6. Statistical parameters of the 2D-QSAR model $(n=5)$.

\begin{tabular}{|c|c|c|c|c|c|}
\hline Model & $\mathrm{R}$ & $\mathrm{R}^{2}$ & $\mathrm{R}_{\text {adj }}^{2}$ & $\mathrm{SD}$ & $\mathrm{F}$ \\
\hline 1 & 0.966 & 0.933 & 0.903 & 0.852 & 34.666 \\
\hline 2 & 0.997 & 0.993 & 0.973 & 0.415 & 49.251 \\
\hline 3 & 0.966 & 0.934 & 0.936 & 0.764 & 54.716 \\
\hline 4 & 0.993 & 0.986 & 0.943 & 0.729 & 22.868 \\
\hline
\end{tabular}

$\mathrm{R}$ : correlation coefficient; $\mathrm{R}^{2}$ : determination coefficient; $\mathrm{R}_{\text {adj }}^{2}$ : adjusted R square; SD: standard deviations; F: F-test value

$$
\begin{gathered}
Y_{\text {second-order interaction }}=-32.714+3.294 \mathrm{AN} \\
+1.210 \mathrm{AW}+2.192 \mathrm{Z}^{2} / \mathrm{r} \\
Y_{\text {synergistic effect }}=-36.881-21.335 \Delta \mathrm{E}_{0} \\
-3.847 \Delta \mathrm{IP}+4.961 \mathrm{IP}
\end{gathered}
$$

$$
\begin{aligned}
Y_{\text {antagonistic effect }}= & 29.935-0.132 \mathrm{Z}^{2} / \mathrm{r}-1.761 \mathrm{Xm} \\
& -23.962 \mathrm{AR}
\end{aligned}
$$

...where $Y_{\text {main effect, }}, Y_{\text {second-order interaction }}, Y_{\text {synergistic effect }}$, and $Y_{\text {antagonistic effect }}$ are the values of the main effect, secondorder interactions effect, synergistic effect and antagonistic effect of the adsorption of the five heavy metals. Additionally, $\Delta \mathrm{IP}$ is the change in ionization potential, IP is the ionization potential, $\left|\log \mathrm{K}_{\mathrm{OH}}\right|$ is the ion hydrolysis ability, AN is the atomic number, AW is the atomic weight, $\mathrm{Z}^{2} / \mathrm{r}$ is the polarizing power, $\Delta \mathrm{E}_{0}$ is electrochemical potential, $\mathrm{Xm}$ is the electronegativity, and $\mathrm{AR}$ is the atomic radius of heavy metals.

As shown in Table 6, the correlation coefficients (R) of the model were $0.966,0.997,0.996$, and 0.993 $(\mathrm{n}=5,>0.8783)$, all of which passed the statistical test $(\mathrm{P}=0.05)$. Additionally, the determination coefficients $\left(\mathrm{R}^{2}\right)$ were $0.933,0.993,0.934$, and 0.986 , and the adjusted $\mathrm{R}$ square $\left(\mathrm{R}_{\text {adj }}^{2}\right)$ values were $0.903,0.973,0.936$, and 0.943 , respectively, indicating that the models have good predictive ability [31-32]. Moreover, the standard deviations (SD) of the model were 0.852, 0.415, 0.764, and 0.729 , and the F-test values were 34.666, 49.251, 54.716 , and 22.868, respectively, demonstrating that the established models had good fits [32].

\section{D-QSAR Model Analysis}

As shown in model (1), a larger ionization potential (IP) and change in ionization potential $(\Delta \mathrm{IP})$ were associated with a greater main effect value of heavy metals adsorption. Additionally, a smaller $\left|\log \mathrm{K}_{\mathrm{OH}}\right|$ value was associated with a stronger hydrolysis ability of heavy metal ions and a greater main effect value of heavy metals adsorption. The IP reflects the affinity and electronegativity of electrons [33] and represents the activity of heavy metal ions and the orbital energy involved in the reaction process. A larger IP value is associated with stronger electron affinity of the heavy metal ions; thus, $\mathrm{Cu}$ is more easily adsorbed onto the sediments because it has the highest IP value among the five heavy metals investigated. This occurs because the main effects of the pollutant factor concentration have greater synergistic effects on $\mathrm{Cu}$ adsorption in the contaminant coexistence system. The $\left|\log \mathrm{K}_{\mathrm{OH}}\right|$ reflects the tendency for connections between heavy metal ions and intermediate ligands (e.g., oxygen-containing groups) [34], with a stronger hydrolysis ability of heavy metal ions being associated with a stronger affinity for intermediate ligands. Kang et al. showed that carboxyl groups play a major role in the adsorption of $\mathrm{Pb}$, while carboxyl and hydroxyl groups play an important role in the adsorption of $\mathrm{Cu}$ [35]. As a result, the combination of heavy metal ions and oxygen-containing groups can promote the adsorption of heavy metals onto sediments.

In model (2), the second-order interaction effect value of heavy metals adsorption increased as the ion characteristic parameters increased ( $\mathrm{AN}, \mathrm{AW}$, and $\mathrm{Z}^{2} / \mathrm{r}$ ). The polarizing power $\left(\mathrm{Z}^{2} / \mathrm{r}\right)$ characterizes the intensity of the interaction between heavy metal ions and sediment components, as well as the tendency to form ionic bonds, which also reflects the energy of the electrostatic interaction between heavy metal ions and ligands [36]. When $Z^{2} / r$ is larger, the interaction of heavy metal ions with sediment components is stronger, and the parameter $\mathrm{Z}^{2} / \mathrm{r}$ has a negative linear relationship with $\left|\log \mathrm{K}_{\mathrm{OH}}\right|[33]$. Specifically, a larger $\mathrm{Z}^{2} / \mathrm{r}$ is associated with a smaller $\left|\log \mathrm{K}_{\mathrm{OH}}\right|$. In other words, a greater ability of ion hydrolysis is associated with a stronger binding capacity of heavy metal ions and intermediate ligands, so the heavy metals are more favorably absorbed onto sediments. Therefore, a high value of $\mathrm{Z}^{2} / \mathrm{r}$ for $\mathrm{Ni}$ is beneficial to absorption onto the sediments, and the second-order interaction effects of pollutant factor concentration have the greatest synergistic effect on the adsorption of $\mathrm{Ni}$ in the composite contamination system. In addition, the atomic weight (AW) increases as the atomic number (AN) increases, with a greater atomic number or atomic weight of the heavy metal making its adsorption onto sediments more favorable.

As shown in model (3), the coefficients of the parameters $\Delta \mathrm{E}_{0}$ and $\Delta \mathrm{IP}$ were both negative, indicating that electrochemical potential $\left(\Delta \mathrm{E}_{0}\right)$ and change in ionization potential ( $\triangle \mathrm{IP}$ ) have a negative effect on the synergistic effect value of heavy metal adsorption, to a certain extent, which can inhibit the adsorption of heavy metals onto the sediment. While the coefficient of the parameter IP is positive (meaning that IP has a positive effect on the synergistic effect value of heavy metals adsorption), it can promote the adsorption of heavy metals onto the sediment. Therefore, $\mathrm{Pb}$, which had the lowest value of $\Delta \mathrm{E}_{0}$, and $\mathrm{Cu}$, which had with the highest IP value, is subject to greater synergism associated with the pollutant factor concentration, resulting in easier adsorption onto the sediments.

As shownin model (4), the coefficients of the parameters $\mathrm{Z}^{2} / \mathrm{r}, \mathrm{Xm}$, and $\mathrm{AR}$ were both negative, indicating that the polarizing power $\left(\mathrm{Z}^{2} / \mathrm{r}\right)$, electronegativity $(\mathrm{Xm})$, and atomic radius (AR) have a negative effect on heavy metals adsorption. Specifically, the inhibition of heavy metals 
adsorption is weakened; therefore, it is conducive to the adsorption of heavy metals onto the sediments. There are different active sites on the surface of the sediment, and high electronegativity can induce strong interactions between active sites and heavy metal ions, resulting in multiple adsorptions of heavy metal ions [37]. In this study, $\mathrm{Pb}, \mathrm{Ni}$, and $\mathrm{Cu}$, which have high electronegativity, were found to be more easily adsorbed onto sediments than $\mathrm{Cd}$ and $\mathrm{Zn}$, which have low electronegativity. These findings are consistent with the conclusion that the competitive adsorption capacity of heavy metals occurs in the order $\mathrm{Ni}>\mathrm{Pb}>\mathrm{Cu}>\mathrm{Cd}>\mathrm{Zn}$. In addition, a greater value of $A R$ was associated with a greater contacting area of heavy metal ions and sediments; thus, it could promote the adsorption of heavy metals onto the sediments. $\mathrm{Pb}$, which has the largest AR value of the 5 investigated heavy metals, is subject to the lower antagonistic effects of the pollutant factor concentration in the contaminant coexistence system; therefore, it can be more easily adsorbed onto sediments. Chen et al. [33] found that the larger ion radius was favorable for the adsorption of heavy metals in a biological adsorption study of $\mathrm{Pb}^{2+}, \mathrm{Ag}^{+}, \mathrm{Cr}^{3+}$, $\mathrm{Cu}^{2+}, \mathrm{Zn}^{2+}, \mathrm{Cd}^{2+}, \mathrm{Co}^{2+}, \mathrm{Sr}^{2+}, \mathrm{Ni}^{2+}$, and $\mathrm{Cs}^{+}$.

The above analysis explored the intrinsic relationship between the values of the main effects, second-order interaction effects, synergistic effects, and antagonistic effects on the adsorption of 5 heavy metals and the physical and chemical properties of heavy metals to provide a basis for further investigation of the adsorption mechanism of heavy metals on sediments in a compound pollution system.

\section{Conclusions}

In this study, resolution $\mathrm{V}$ of the $2^{10-3}$ fractional factorial design method with the fixed effect model was used to identify the significant $(P=0.05)$ main effects and the second-order interaction effects of the pollutant factor concentration on the adsorption of copper, lead, and zinc in a heavy-metals (copper, cadmium, lead, zinc, and nickel) and pesticides (dimethoate, metalaxyl, atrazine, malathion, and prometryn) coexistence system. Further, the effect values and the contribution rates of synergistic and antagonistic effects were calculated, and the competitive capacity of sediments for adsorption of heavy metals was determined. Moreover, the quantitative structure-activity relationship between effect values of heavy metals adsorption and physical and chemical properties of heavy metals was established by 2D-QSAR models to reveal the physical and chemical properties of heavy metals influencing the effect values of heavy metals adsorption in a composite contamination system. The results provided herein will serve as the foundation for further investigation of the transformation of heavy metals and optimal regulation of pollution.

\section{Acknowledgements}

The authors are grateful for the financial support provided by the Ministry of Science and Technology of China ('973' project No. 2004CB3418501), and thank Jeremy Kamen, MSc, from Liwen Bianji, Edanz Group China (liwenbianji.cn/ac), for editing the English text of a draft of this manuscript.

\section{References}

1. BAI J., CUI B., CHEN B., ZHANG K., DENG W., GAO H., XIAO R. Spatial distribution and ecological risk assessment of heavy metals in surface sediments from a typical plateau lake wetland, China. Ecol. Model. 222 (2), 301, 2011.

2. SULTANA M.S., JOLLY Y.N., YEASMIN S., ISLAM A., SATTER S., TAREQ S.M. Chapter 12-Transfer of heavy metals and radionuclides from soil to vegetables and plants in Bangladesh. Soil Remediation and Plants. 331, 2015.

3. HUSAIN A., ASHHAR M.M., JAVED I. Analysis of industrial wastewater in Aligarh City. J. Chem. Pharm. Res. $6(1), 614,2014$

4. D'AMATO G., PAWANKAR R., VITALE C., LANZA M., MOLINO A., STANZIOLA A., SANDUZZI A., VATRELLA A., D'AMATO M. Climate change and air pollution: effects on respiratory allergy. Allergy Asthma Immu. Res. 8 (5), 391, 2016.

5. GOVIL P.K., SORLIE J.E., MURTHY N.N. Soil contamination of heavy metals in the Katedan Industrial Development Area, Hyderabad, India. Environ. Monit. Assess. 140 (1-3), 313, 2008.

6. MUSTAFA G., KOMATSU S. Toxicity of heavy metals and metal-containing nanoparticles on plants. BBA-Proteins Proteom. 1864 (8), 932, 2016.

7. JU Y.R., CHEN C.W., CHEN C.F., CHUANG X.Y., DONG C.D. Assessment of heavy metals in aquaculture fishes collected from southwest coast of Taiwan and human consumption risk. Int. Biodeter. Biodegr. 124, 314, 2017.

8. CHI T.V., LIN C., SHERN C.C., YEH G., LE V.G., TRAN H.T. Contamination, ecological risk and source apportionment of heavy metals in sediments and water of a contaminated river in Taiwan. Ecol. Indic. 82, 32, 2017.

9. BILLIONNET C., SHERRILL D., ANNESI-MAESANO I. Estimating the health effects of exposure to multi-pollutant mixture. Ann. Epidemiol. 22 (2), 126, 2012.

10. GHAZY H.A., MAS A.R., EI NAHAS A.F., MAHMOUD S. Assessment of complex water pollution with heavy metals and Pyrethroid pesticides on transcript levels of Metallothionine and immune related genes. Fish Shellfish Immun. 68, 318, 2017.

11. JAIN C.K., GUPTA H., CHAKRAPANI G.J. Enrichment and fractionation of heavy metals in bed sediments of River Narmada, India. Environ. Monit. Assess. 141, 35, 2008.

12. WEI M., QIN Y., ZHENG B., ZHANG L. Heavy metal pollution in Tianjin Bohai Bay, China. J. Environ. Sci. 20 (7), 814, 2008.

13. BARJHOUX I., CLÉRANDEAU C., MENACH K.L., ANSCHUTZ P., GONZALEZ P., BUDZINSKI H., MORIN B., BAUDRIMONT M., CACHOT J. A comprehensive study of the toxicity of natural multi-contaminated sediments: New insights brought by the use of a combined 
approach using the medaka embryo-larval assay and physico-chemical analyses. Ecotoxicol. Environ. Saf. 142, 509, 2017.

14. WANG C., LIU S., ZHAO Q., DENG L., DONG S. Spatial variation and contamination assessment of heavy metals in sediments in the Manwan Reservoir, Lancang River. Ecotoxicol. Environ. Saf. 82, 32, 2012.

15. GUO S.H., WANG X.L., LI Y., CHEN J.J., YANG J.C. Investigation on $\mathrm{Fe}, \mathrm{Mn}, \mathrm{Zn}, \mathrm{Cu}, \mathrm{Pb}$ and $\mathrm{Cd}$ fractions in the natural surface coating samples and surficial sediments in the Songhua River, China. J. Environ. Sci. 18 (6), 1193, 2006.

16. GAO L., WANG Z., SHAN J., CHEN J., TANG C., YI M., ZHAO X. Distribution characteristics and sources of trace metals in sediment cores from a trans-boundary watercourse: an example from the Shima River, Pearl River Delta. Ecotoxicol. Environ. Saf. 134, 186, 2016.

17. LI S.S., GAO Q., WANG X.L., LI Y. Using multiple regression adsorption models to estimate $\mathrm{Zn}$ and $\mathrm{Cu}$ adsorptions onto Fe oxides, Mn oxides, organic materials and their blends in surficial sediments. Fresenius Environ. Bull. 19 (8), 1466, 2010.

18. LI H., SHENG Y., YE J., FAN J., GAO M., HAO G. Baseline survey of sediments and marine organisms in Liaohe estuary: heavy metals, polychlorinated biphenyls and organochlorine pesticides. Mar. Pollut. Bull. 114 (1), $555,2016$.

19. FONTES M.P.F., SANTOS G.C.D. Santos. Lability and sorption of heavy metals as related to chemical, physical, and mineralogical caracteristics of highly weathered soils. J. Soil. Sediment. 10 (4), 774, 2010.

20. LI X., WANG Y., Li B., FENG C., CHEN Y., SHEN Z. Distribution and speciation of heavy metals in surface sediments from the Yangtze estuary and coastal areas. Environ. Earth Sci. 69 (5), 1537, 2013.

21. WEI T., LI G., MEI B., MIN Y., PENG J., BARROW C.J., YANG W., WANG H. The study of adsorption mechanism of mixed pesticides prometryne-acetochlor in the soil-water system. Int. Biodeterior. Biodegrad. 102, 281, 2015.

22. CHENG B., LI S., WANG M., LI Y. Investigation of combined pollution between malathion and a variety of pollutants based on the fractional factorial design (resolution IV). Pol. J. Environ. Stud. 24 (5), 1939, 2015.

23. WANG M., LI X.L., LI Y. Characteristic of competitive adsorption of dimethoate with a variety of pollutants on surficial sediments through fractional factorial design, Adv. Mater. Res. 599, 467, 2012.

24. GU W.W., CHENG B.C., LI Y. Interference adsorption of cadmium with a variety of pollutants in sediments based on fractional factorial design (resolution V). Pol. J. Environ. Stud. 26 (1), 47, 2017.
25. CHENG B.C. Adsorption mechanism of heavy metals and pesticides in sediments based on fractional factorial design (resolution V), master degree thesis. North China Electric Power University, Beijing, China. 2015 [In Chinese].

26. LI Y., GAO Q., WANG X.L., DONG D.M., WANG A. Synergetic and antagonistic effects of cadmium on the adsorption of atrazine in the surficial sediments. Chem. Res. Chinese Universities. 25 (2), 155, 2009.

27. DUCHOWICZ P.R., CASTAŇETA H., CASTRO E.A., FERNÁNDEZ F.M., VICENTE J. L. QSPR prediction of the Dubinin-Radushkevich's $k$ parameter for the adsorption of organic vapors on BPL carbon. Atmos. Environ. 40 (16), 2929, 2006.

28. LI Y., LI X.L., DU X.Y., WANG M., XIN J., HU Y., WANG Y. Using the QICAR model to correlate metal ion characteristics with toxicity order numbers. Hum. Ecol. Risk Assess. 18 (6), 1255, 2012.

29. MCCLOSKEY J.T., NEWMAN M.C., CLARK S.B. Predicting the relative toxicity of metal ions using ion characteristics: Microtox ${ }^{\circledR}$ bioluminescence assay. Environ. Toxicol. Chem. 15 (10), 1730, 1996.

30. WOLTERBEEK H.T., VERBURG T.G. Predicting metal toxicity revisited: general properties vs. specific effect. Sci. Total Environ. 279 (1-3), 87, 2001.

31. LITON M.A.K., SALMA U., BHOWMICK A.C. Cytotoxicity and 2D-QSAR study of some heterocyclic compounds. Arabian J. Chem. 7 (5), 639, 2014.

32. SONI H.M., PATEL P.K., CHHABRIA M.T., RANA D.N., MAHAJAN B.M., BRAHMKSHATRIYA P.S. 2D-QSAR study of a series of pyrazoline-based anti-tubercular agents using genetic function approximation. Comput. Chem. 3 (4), 45, 2015.

33. CHEN C., WANG J.L. Correlating metal ionic characteristics with biosorption capacity of an yeast using QSAR model based on classifications of metal ions. Acta Scien. Circum. 28 (1), 76, 2008 [In Chinese].

34. ZHOU D.M., LI L.Z., PEIJNENBURG W.J., OWNBY D.R., HENDRIKS A.J., WANG P., LI D. A QICAR approach for quantifying binding constants for metal-ligand complexes. Ecotoxicol. Environ. Saf. 74 (4), 1036, 2011.

35. KANG D.J., XIE D.Y., KUANG S., JIANG X., SUN J., TANG H., FU F.F. Adsorption mechanism of extracellular polymeric substances in activated sludge on $\mathrm{Pb}^{2+}$ and $\mathrm{Cu}^{2+}$. China Water \& Wastewater. 32 (21), 28, 2016 [In Chinese].

36. CHEN C., WANG J.L. Correlating metal ionic characteristics with biosorption capacity using QSAR model. Chemosphere, 69 (10), 1610, 2007.

37. BEHNAMFARD A., SALARIRAD M.M. Equilibrium and kinetic studies on free cyanide adsorption from aqueous solution by activated carbon. J. Hazard. Mater. 170 (1), 127, 2009. 
